\title{
PENGEMBANGAN MODEL ADDIE BAGI PEMBELAJARAN DARING MATA KULIAH PENGANTAR HUKUM INDONESIA UNIVERSITAS NEGERI SURABAYA
}

\author{
Emmilia Rusdiana, Arinto Nugroho, Siti Maizul Habibah \\ Fakutas Ilmu Sosial dan Hukum, Universitas Negeri Surabaya, Kampus UNESA Ketintang Surabaya. \\ Email: emmiliarusdiana@unesa.ac.id
}

\begin{abstract}
The learning process is by following with the Semester Learning Plan (RPS) that has been prepared by the lecturer at the beginning of the lecture, but the lecturer sometimes experiences some obstacles so that the lecture does not go well. Lectures are conducted $15 x$ face-to-face, and Unesa has provided $4 x$ online facilities. Online lecture facilities are an important part of learning today because online lectures can replace face-to-face learning, so this is the reason for developing online lectures. This research was conducted to determine the readiness of tertiary institutions for digital challenges and student responses to online lectures. The research uses the addie method and data collection uses structured interviews and analyzed with descriptive qualitative. The results and discussion show that the development of online lectures in Indonesian Law Introduction (PHI) courses using teaching materials that are practical and easily understood by S1 Law students through several stages ranging from mapping, implementing online media creation, online lecturing and evaluating online done through assignments. Implementation of online lectures requires an evaluation of the preparation of tertiary institutions, lecturers and students. Some input in terms of media and content has been improved by the research team and online learning is ready to be given to students.
\end{abstract}

Keywords: The Addie method, Introduction to Indonesian Law, media experts, legal experts, online learning

\section{PENDAHULUAN \\ Latar Belakang}

Penegakkan

hukum belum menampakkan keberhasilan sesuai dengan harapan masyarakat, dan hukumpun menjadi tidak bermartabat, yang pada akhirnya akan menimbulkan eigenrichting (main hakim sendiri), di mana masyarakat akan mengadili sendiri pelaku tindak pidana secara brutal. Salah satu langkah strategis untuk mengatasi tantangan tersebut adalah dengan cara membina moralitas serta meningkatkan kecakapan hukum bagi para mahasiswa sebagai kader-kader pemimpin masyarakat, bangsa, dan pemimpin pemerintahan di masa depan, kualitas mahasiswa seperti itu cenderung berpengaruh positif terhadap peningkatan kualitas masyarakat.
Mahasiswa senantiasa berperan penting dalam melakukan fungsi kontrol sosial baik terhadap masyarakat, jalannya pemerintahan maupun terhadap aparat penegak hukum. Dengan demikian membina wawasan hukum, moral, dan kecakapan proses penegakan hukum merupakan kecerdasan mahasiswa yang sangat penting untuk dikembangkan dan memiliki peran strategis dalam meningkatkan suasana kondusif, ketertiban, keamanan dan keadilan. Oleh karena itu logis apabila pemerintah memprioritaskan pengembangan kompetensi para generasi penerus calon pemimpin bangsa tersebut melalui mata kuliah Pengantar Hukum Indonesia.

Pengantar Hukum Indonesia merupakan salah satu mata kuliah wajib program studi S1 Ilmu Hukum dan S1 
Pendidikan Kewarganegaraan dan S1 Administrasi Negara yang bertujuan untuk meningkatkan pengetahuan mahasiswa tentang sejarah hukum di Indonesia dan pembidangan hukum. Upaya awal untuk mengadakan penegakan hukum adalah adanya pemahaman tentang Pengantar Hukum Indonesia (PHI), tujuan dari belajar PHI ini adalah untuk mengetahui peraturan-peraturan hukum yang berlaku saat ini di suatu wilayah negara atau hukum positif (Ius Constitutum), untuk mengetahui perbuatan-perbuatan mana yang berdasarkan hukum, atau bahkan melanggar hukum, untuk mengetahui kedudukan seseorang dalam masyarakat atau hak dan kewajibannya, untuk mengetahui sanksi-sanksi apabila orang tersebut melanggar peraturan yang berlaku atau untuk mempelajari hukum yang mencakup seluruh lapangan hukum yang berlaku di Indonesia, baik itu hukum yang tertulis maupun hukum yang tidak tertulis.

Program studi S1 Ilmu Hukum merupakan prodi yang mencetak caloncalon penegak hukum yang harus memiliki intelegensi tinggi, menjunjung tinggi moral dan berguna bagi masyarakat dengan menjunjung tinggi kebenaran dan keadilan, maka pengenalan akan Pengantar Hukum Indonesia merupakan sesuatu yang sangat mendesak, begitu juga dengan mahasiswa Program Studi S1 Kewarganegaraan di mana menuntut mahasiswa untuk mengembangkan ide-ide, menemukan sesuatu yang baru dan melatih dirinya dalam situasi yang nyata sebagai anggota masyarakat dalam kehidupan yang sangat kompleks yaitu bermasyarakat, berbangsa dan bernegara, sementara dalam Prodi S1 Administrasi Negara memiliki komitmen untuk menghasilkan lulusan administrasi negara yang berdaya saing secara moral dan profesional guna meningkatkan kualitas hidup masyarakat.

Hal ini merupakan tantangan tersendiri, karena data menunjukkan bahwa materi mata kuliah di perguruan tinggi masih dipandang kurang menunjang terhadap pengembangan kesadaran dan kecakapan mahasiswa dalam berpartisipasi mewujudkan kebijakan yang berorientasi kepada kepentingan publik, berbasis rasa kebangsaan dan cinta tanah air (Nurdin, 2016)

Berkaitan dengan upaya meningkatkan pemahaman mahasiswa akan PHI dan dalam rangka mendukung program kuliah daring di Unesa, maka pengampu mata kuliah PHI berperan serta dalam pembuatan daring dengan penelitian pengembangan kuliah PHI daring berbasis multimedia. Kegiatan penelitian kuliah daring mata kuliah PHI berbasis multimedia pada tahun 2019 ini bertujuan :

1. Meningkatkan pelaksanaan kualitas perkuliahan daring (dalam jaringan) mata kuliah Pengantar Hukum Indonesia untuk mahasiswa Unesa.

2. Mendiskripsikan respon mahasiswa terhadap pembelajaran daring materi digital berbasis interaktif-multimedia pada mata kuliah Pengantar Hukum Indonesia.

\section{Metode Penelitian}

Jenis penelitian pengembangan. Dalam penelitian ini digunakan pendekatan Analyze, Design, Develop, Implement, and Evaluate (ADDIE). Tujuan dari analyze sebagaimana diungkapkan adalah "to identify the probable causes for a performance gap". Selanjutnya, tujuan dari Design adalah to verify the desired performances and appropriate testing methods, the Develop phase is to generate and validate the learning resources that will be required during the life of the instructional modules, The purpose of the Implement phase is to prepare the learning environment and engage the students. The purpose of the Evaluate phase is to assess the quality of the instructiona products and processes, both before and after implementation. (Branch; 2009). 


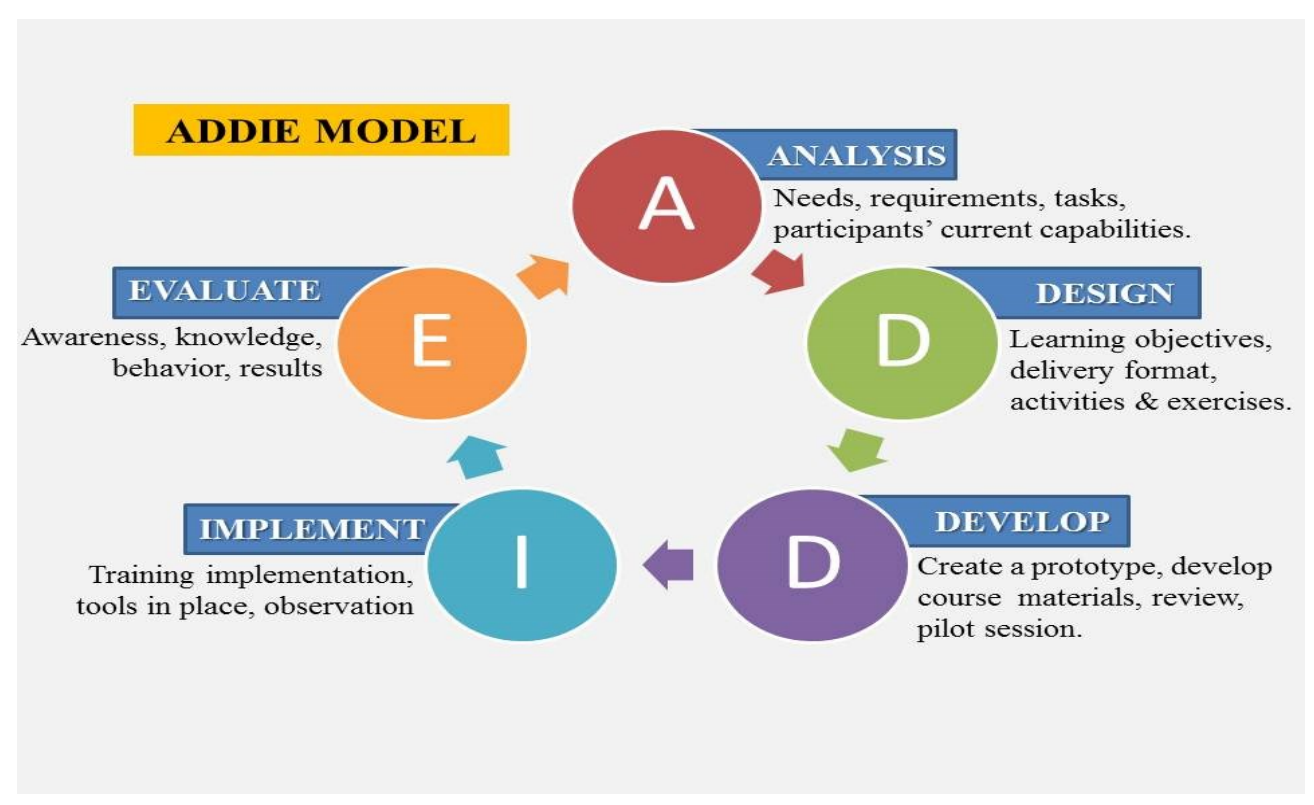

Gambar: pendekatan Analyze, Design, Develop, Implement, and Evaluate

\section{(ADDIE).}

Tujuan analisis adalah untuk mengidentifikasi permasalahan yang dihadapi oleh peneliti. Dari permasalahan tersebut maka desain sebagai sebuah upaya yang akan dilakukan untuk mengatasi persoalan. Langkah selanjutnya adalah pengembangan dimana dalam fase ini dimaksudkan unruk memastikan dan memvalidasi bahan ajar yang akan digunakan, setelah divalidasi maka bahan ajar akan diterapkan pada pembelajaran di kelas dan melihat efek dari penerapan tersebut, dan angkah terakhir adalah mengevaluasi kualitas dari bahan ajar tersebut.

. Berkaitan dengan pelaksanaan penelitian ini, dengan menggunakan pendekatan ADDIE, yang meliputi:

1. menganalisis kebutuhan bahan ajar, yang meliputi analisis Standar Kompetensi (SK) dan Kompetensi Dasar (KD), analisis sumber belajar, analisis dilakukan terhadap ketersediaan, kesesuaian dan kemudahan dalam memanfaatkannya.

2. Mendesain bahan ajar, Langkahlangkah yang dilakukan dalam menyusun bahan ajar, yakni merancang outline buku yang mencakup seluruh aspek yang diperlukan untuk mencapai suatu kompetensi, mengumpulkan referensi terkini dan relevan, sebagai bahan penulisan, menggunakan berbagai sumber belajar yang dapat memperkaya materi, memperhatikan penyajian kalimat yang disesuaikan dengan usia dan pengalaman mahasiswa.

3. Implementasi di dalam kelas dengan meminta mahasiswa untuk membaca dan memberikan soal sebagai bahan evaluasi.

4. Tahap pengembangan, tahap ini merupakan tahap realisasi produk. Pengembangan bahan ajar dilakukan sesuai dengan rancangan. Setelah itu, bahan ajar tersebut divalidasi oleh ahli yang 
terdiri dari ahli materi dan ahli media. Pada proses validasi, validator menggunakan instrumen yang sudah disusun pada tahap sebelumnya. Validasi dilakukan untuk menilai validitas isi dan konstruk. Validator diminta memberikan penilaian terhadap bahan ajar yang dikembangkan berdasarkan butir aspek kelayakan bahan ajar serta memberikan saran dan komentar berkaitan dengan isi bahan ajar yang nantinya akan digunakan sebagai patokan revisi perbaikan dan penyempurnaan bahan ajar. validasi dilakukan hingga pada akhirnya bahan ajar dinyatakan layak untuk diimplementasikan dalam kegiatan pembelajaran. pada tahap ini, peneliti juga melakukan analisis data terhadap hasil penilaian bahan ajar yang didapatkan dari validator. hal ini dilakukan untuk mendapatkan nilai kevalidan bahan ajar.

5. Memberikan penilaian (evaluasi dan revisi). Evaluasi dilakukan untuk mengetahui kelayakan bahan ajar dengan asumsi sudah layak atau masih ada hal yang perlu diperbaiki. Teknik evaluasi dilakukan dengan cara memberikan instrumen evaluasi kepada para ahli berupa angket terbuka

Berdasarkan masukan (data) yang diperoleh dari instrumen evaluasi, selanjutnya dianalisis secara deskriptif kualitatif, yang pada akhirnya akan menjadi bahan untuk memperbaiki (merevisi) bahan ajar dalam pembelajaran daring.

\section{Hasil Penelitian dan Pembahasan}

Bahan ajar adalah segala bentuk bahan berupa seperangkat materi yang disusun secara sistematis untuk membantu guru/instruktur dalam melaksanakan kegiatan pembelajaran dan memungkinkan siswa untuk belajar. Kualitas bahan ajar mata kuliah PHI dilihat dari penilaian para pakar pada segi materi/isi dan media, jadi dalam proses pembuatannya mengalami beberapa masukan dari tim ahli.

1. Analisis kebutuhan bahan ajar

2. Mendesain bahan ajar

3. Implementasi pembelajaran di kelas

4. Pengembangan bahan ajar

Cara mengembangkan kelayakan bahan ajar, yaitu membuat draf materi yang diunggah pada VINESA, dan dilakukan perbaikan sesuai dengan masukan tim ahli yang terdiri dari dua orang, yaitu segi media yaitu Dr. Sukma Perdana Setya, S.Pd.M.T. dan segi materi/konsep yakni Dr. Pudji Astuti, S.H.M.H.

Berikut ini adalah hasil instrumen atas masukan tim ahli substansi atau isi yaitu Dr. Pudji Astuti, S.H.M.H.

Tabel 1; Instrumen atas Masukan Tim Ahli Substansi

\begin{tabular}{|c|c|c|c|}
\hline \multirow[t]{2}{*}{ No. } & \multirow[t]{2}{*}{ Variabel } & \multirow[t]{2}{*}{ Indikator } & Hasil Evalusi \\
\hline & & & $\begin{array}{ll}\text { ya } & \text { tidak } \\
\end{array}$ \\
\hline \multirow{3}{*}{\multicolumn{2}{|c|}{ 1. Kelengkapan materi }} & 1. Kelengkapan materi & $\mathrm{v}$ \\
\hline & & 2. Keluasan materi & $\mathrm{v}$ \\
\hline & & 3. $\quad$ Kedalaman materi & $\overline{\mathrm{v}}$ \\
\hline \multirow{2}{*}{\multicolumn{2}{|c|}{ 2. Keakuratan materi }} & 4. Keakuratan konsep dan definisi & $\mathrm{v}$ \\
\hline & & 5. Keakuratan data dan fakta & $\mathrm{v}$ \\
\hline
\end{tabular}




\begin{tabular}{|c|c|c|c|c|}
\hline & 6. & Keakuratan contoh dan kasus & $\mathrm{v}$ & \\
\hline & 7. & Keakuratan gambar dan ilustrasi & & $\mathrm{v}$ \\
\hline & 8. & Keakuratan istilah-istilah & $\mathrm{v}$ & \\
\hline 3 & Kesesuaian materi & $\begin{array}{lcr}\text { Kesesuaian } & \text { materi } & \text { dengan } \\
\text { nerkembanoan ilmu nengetahuan }\end{array}$ & & $\mathrm{v}$ \\
\hline 4 & Kemutakhiran materi 10 & . Kemutakhiran pustaka & $\mathrm{v}$ & \\
\hline 5 & $\begin{array}{l}\text { Peningkatan motivasil } 1 \\
\text { mahasiswa }\end{array}$ & $\begin{array}{l}\text { Mendorong rasa ingin tahu peserta } \\
\text { didik }\end{array}$ & & $\mathrm{v}$ \\
\hline & & $\begin{array}{l}\text { Menciptakan } \\
\text { peserta didik }\end{array}$ & & $\mathrm{v}$ \\
\hline
\end{tabular}

Hasilnya adalah keakuratan materi menunjukkan bahwa gambar yang ditampilkan pada sebaiknya diberikan ilustrasi dan kesesuaian materi dengan perkembangan Ilmu Pengetahuan Sosial (IPS) serta rasa ingin tahu peserta didik belum diakomodasikan dalam penyusunan media pembelajaran serta upaya menciptakan kemampuan bertanya peserta didik belum tampak. Jadi menurut pakar ahli subtansi bahwa konten dapat disempurnakan lagi berdasarkan masukan pada lembar validasi sehingga konten atau subtansi materi tersampaikan sesuai tujuan pembelajaran.

Sementara itu hasil penilaian pakar media Dr. Sukma Perdana Setya, S.Pd.M.T. mengenai media atau kegrafikan dapat ditunjukkan oleh tabel berikut ini :

\section{Tabel 2; Hasil Penilaian Pakar Media}

\begin{tabular}{|c|c|c|c|}
\hline \multirow[t]{2}{*}{ Variabel } & \multirow[t]{2}{*}{ Indikator } & \multicolumn{2}{|c|}{ Hasil Evalusi } \\
\hline & & ya & tidak \\
\hline \multirow[t]{3}{*}{ 1. Kecermatan Isi } & 1. Valid & $\begin{array}{l}\mathrm{V} \\
\end{array}$ & \\
\hline & 2. Selaras nilai sosial & $\mathrm{V}$ & \\
\hline & 3. Mutakhir & $\mathrm{V}$ & \\
\hline \multirow[t]{3}{*}{ 2. Ketepatan Cakupan Isi } & $\begin{array}{l}\text { 1. Keluasan sesuai dengan tujuan } \\
\text { instruksional }\end{array}$ & 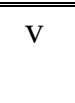 & \\
\hline & $\begin{array}{l}\text { 2. Kedalaman sesuai dengan tujuan } \\
\text { instruksional }\end{array}$ & $\mathrm{v}$ & \\
\hline & 3. Keutuhan konsep & $\mathrm{V}$ & \\
\hline \multirow[t]{6}{*}{ 3. Ketercernaan } & 1.Logis & $\mathrm{v}$ & \\
\hline & 2. Runtut & $\mathrm{v}$ & \\
\hline & 3. Cukup contoh \& ilustrasi & $\mathrm{v}$ & \\
\hline & 4. Format konsisten & & $\mathrm{V}$ \\
\hline & 5. Ada penjelasan relevansi & $\mathrm{V}$ & \\
\hline & 6. Ada penjelasan manfaat & $\mathrm{v}$ & \\
\hline \multirow[t]{2}{*}{ 4. Penggunaan Bahasa } & 1. Ragam bahasa komunikatif & $\mathrm{v}$ & \\
\hline & 2. Kata singkat dan lugas & $\overline{\mathrm{V}}$ & \\
\hline
\end{tabular}




\begin{tabular}{|c|c|c|c|}
\hline & 3. Ada daftar senarai & & $\mathrm{V}$ \\
\hline & 4. Kalimat efektif & $\mathrm{V}$ & \\
\hline & 5. Paragraf memiliki gagasan utama & $\mathrm{V}$ & \\
\hline & $\begin{array}{l}\text { 6. Kalimat-kalimat dalam paragraf } \\
\text { terpadu }\end{array}$ & $\overline{\mathrm{V}}$ & \\
\hline & $\begin{array}{l}\text { 7. Kalimat-kalimat dalam paragraf } \\
\text { koheren }\end{array}$ & $\mathrm{V}$ & \\
\hline \multirow[t]{9}{*}{ 5. Perwajahan } & 1. Narasi tidak terlalu padat & $\mathrm{V}$ & \\
\hline & 2. Ada bagian kosong & & $\mathrm{V}$ \\
\hline & 3. Kalimat pendek & & $\overline{\mathrm{V}}$ \\
\hline & 4. Grafik dan gambar bermakna & & $\mathrm{V}$ \\
\hline & 5. Penomoran benar & $\mathrm{v}$ & \\
\hline & 6. Penomoran konsisten & $\begin{array}{l}\mathrm{V} \\
\end{array}$ & \\
\hline & 7. Huruf menarik & $\mathrm{v}$ & \\
\hline & 8. Huruf tidak membingungkan & $\mathrm{V}$ & \\
\hline & $\begin{array}{l}\text { 9. Ada alat bantu dibagiab awal, } \\
\text { pembahasan, dan akhir. }\end{array}$ & $\mathrm{v}$ & \\
\hline \multirow[t]{3}{*}{ 6. Illustrasi } & 1. Ada illustrasi & $\mathrm{v}$ & \\
\hline & 2. Illustrasi menarik & & $\mathrm{V}$ \\
\hline & 3. Illustrasi Komunikatif & & $\mathrm{V}$ \\
\hline \multirow[t]{4}{*}{$\begin{array}{ll}\text { 7. Kelengkapan } \\
\text { Komponen } \\
\end{array}$} & 1. Ada uraian & $\mathrm{v}$ & \\
\hline & 2. Ada latihan & $\mathrm{v}$ & \\
\hline & 3. Ada umpan balik & $\mathrm{V}$ & \\
\hline & 4. Ada penguatan & $\mathrm{v}$ & \\
\hline
\end{tabular}

Hasilnya ada perubahan RPS sesuai masukan dari Pakar media yaitu Dr. Sukma Perdana Setya, S.PD.M.T. pada kemampuan akhir, indikator pembelajaran dan latihan serta tugas yang merangsang mahasiswa dalam analisis PHI. Jadi dapat dinyatakan bahwa ada segi ketercernaan, maka Format konsisten masih perlu diperbaiki, daftar senarai perlu ditambahkan sehingga konten (isi) dapat dipertanggungjawabkan kemudian pada segi perwajahan, perbaikan perlu diebrikan pada bagian yang kosong, kalimat terlalu pendek dan grafik dan gambar terkadang bermakna, cetak miring pada kata atau kalimat asing dan secara keseluruhan sudah mengacu pada penggunaan bahasa Indonesia yang baik dan benar.
Berdasarkan tabel tersebut dapat ditarik kesimpulan bahwa beberapa masukan dari segi media dan konten (isi) telah diperbaiki oleh tim peneliti dan pembelajaran daring telah siap untuk diberikan pada mahasiswa.

Pelaksanaan perkuliahan daring (dalam jaringan) atau e-learning mata kuliah Pengantar Hukum Indonesia bagi mahasiswa Unesa

Media daring adalah segala bentuk bahan yang digunakan untuk membantu dosen dalam melaksanakan kegiatan belajar mengajar di kelas. Bahan yang dimaksud bisa berupa bahan tertulis maupun bahan tidak tertulis. Dosen perlu mengembangkan media daring karena dosen harus memiliki 
atau menggunakan bahan ajar yang sesuai dengan :

a. Kurikulum, dalam hal ini bahan ajar yang telah dihasilkan mulai dari penyusunan telah didesain untuk mengikuti Kerangka Kualifikasi Nasional Indonesia (KKNI), sehingga pembuatan bahan ajar melalui proses mulai dari pemetaan Rencana Perkuliahan Semester (RPS) yakni capaian pembelajaran sampai dengan metode yang dilakukan telah disesuaikan antara RPS yang telah disusun dengan bahan ajar yang dikembangkan.

b. Karakteristik sasaran, sasaran yang dimaksud disini adalah mahasiswa, mahasiswa S-1 Hukum yang mewakili mahasiswa S1 Administrasi Negara dan S1 Pendidikan kewarganegaraan Universitas Negeri Surabaya. Mahasiswa yang menempuh matakuliah PHI pada semester gasal periode 2019/2020 terdapat tiga kelas yakni kelas 2019 A, 2019 B dan 2019 C.

c. Media daring yang baik sebagai salah satu dari metode pengajaran yang dihasilkan dengan syarat minimal memiliki prasyarat kualitas materi, kualitas pembelajaran atau pedagogis yang memadai dan tingkat keterbacaan yang relevan dengan kebutuhan atau tingkat pemahaman dan kemampuan berpikir pembaca, sehingga dalam penyusunannya perlu diperhatikan pada aspek kurikulum, kebutuhan dari sasaran, dan karakteristik sasaran. Untuk itu bahan ajar yang akan dihasilkan memerlukan penilaian dari para pakar yaitu pakar subtansi, pakar bahasa dan pakar pedagogi sehingga bahan ajar tersebut dapat dipertanggungjawabkan kelayakannya.

d. Dalam pengembangan materi PHI yang telah dilakukan dalam daring (elektronik) sudah memenuhi komponen isi/materi, pedagogis, dan bahasa meskipun belum sempurna. Secara keseluruhan pengembangan bahan ajar mata kuliah PHI yang dihasilkan dinyatakan baik namun masih memerlukan uji coba ke mahasiswa, sehingga akan diketahui respon dari mahasiswa untuk mengidentifikasi efektivitasnya.

Pembahasan pertama adalah mengenai respon mahasiswa berkaitan dengan persiapan perguruan tinggi dalam pembelajaran daring. Pada fasilitas penyelenggaraan pembelajaran daring yang saat ini digunakan oleh dosen mengenai ragam aktivitas dan tool ASINKRON yang digunakan dalam sistem pembelajaran daring di perguruan tinggi yang penggunaannya rata-rata diperuntukan untuk forum diskusi, email dan whatsapp. Kesiapan sistem pendukung yang tersedia di perguruan tinggi untuk melakukan perkuliahan daring adalah 56,17\% Server dan sistem jaringan telah memadai sedangkan 41,57\% menyatakan cukup memadai (labil). Ketertarikan mahasiswa pada tampilan perkuliahan daring dalam VINESA UNESA begitu tinggi 47,19\% menarik dan diikuti $39,32 \%$ biasa saja.

Pembahasan kedua mengenai motivasi mahasiswa dalam pembelajaran daring. Salah satu motivasi mahasiswa ditunjukkan dengan Ketertarikan mahasiswa saat mengetahui ada perkuliahan dengan daring yaitu $67,41 \%$ tertarik. Lalu kegiatan mahasiswa sehubungan dengan persiapan perkuliahan daring mata kuliah sebesar 69,33\% dengan sebagian kecil telah mengakses materi. Sedangkan mengenai ketertarikan mahasiswa dengan mengadakan eksplorasi untuk mata kuliah lain yakni 57,3\%. Mengenai motivasi saat mahasiswa mengikuti perkuliahan daring mata kuliah adalah $71 \%$ mengaku termotivasi. Alasan mahasiswa mengikuti perkuliahan daring pada VINESA lebih pada instruksi dari dosen yaitu $60,67 \%$ selebihnya karena pemanfaatan perkembangan iptek, dan desain (tampilan) slide PPT perkuliahan daring $78,61 \%$ mahasiswa menyatakan menarik. 
Pembahasan ketiga adalah mengenai materi pada pembelajaran daring bahwa kesesuaian materi daring dengan tujuan pembelajaran mata kuliah $87,6 \%$ rata-rata mahasiswa menyatakan sesuai. Sedangkan selanjutnya mengenai kualitas materi berkaitan dengan kebenaran dan akurasi materi perkuliahan daring, bahwa pernyataan paling tinggi yaitu sesuai dengan kebenaran dan akurasi. Mengenai kualitas materi berkaitan dengan keberimbangan penyajian ide materi perkuliahan daring $\quad 47,19 \%$ menyatakan ada keberimbangan penyajian ide. Sedangkan sejalan dengan itu terkait kualitas materi berkaitan dengan ketepatan tingkat kerincian (keluasan dan kedalaman materi perkuliahan daring rata-rata menyatakan tidak tahu dan Efektifitas pencapaian tujuan pembelajaran dengan perkuliahan daring dibanding perkuliahan tatap muka $76,40 \%$ menyatakan efektif. Ragam objek ajar apa saja yang digunakan dalam pembelajaran daring yaitu sebagai berikut :teks, audio, visual, audio visual, animasi, games dan simulasi dan pada penerapannya menggunakan audio visual pada posisi tertinggi. Menurut pendapat mahasiswa antara kebutuhan perkuliahan daring dengan perkuliahan tatap muka adalah dengan komposisi perkuliahan masing-masing sebanyak 50\%.

Analisis atas respon mahasiswa terhadap pembelajaran daring pada mata kuliah Pengantar Hukum Indonesia.

Salah satu tujuan dari pelaksanaan perkuliahan daring adalah sebagai variasi materi dan cara mengembangkan perkuliahan, selain untuk memanfaatkan ilmu pengetahuan dan teknologi (IPTEK) dan efektifitas atau efisiensinya. Pengembangan perkuliahan dengan daring pada mata kuliah PHI dengan menggunakan bahan ajar yang praktis dan mudah dipahami oleh mahasiswa S1 Hukum melalui beberapa tahap mulai dari pemetaan, pelaksanaan pembuatan media daring, pelaksanaan perkuliahan secara daring dan evaluasi yang dilakukan melalui tugas.
Ada tiga kategori pembahasan mengenai respon mahasiswa yaitu persiapan perguruan tinggi, motivasi mahasiswa dan data mengenai materi pada pembelajaran daring. Pada masing-masing kategori saling mempengaruhi, maksudnya adalah persiapan perguruan tinggi lebih dahulu ada, baru kemudian motivasi mahasiswa untuk menggunakan fasilitas tersebut dengan dukungan materi mata kuliah dari dosen mengenai penyediaan materi dengan pembelajaran daring.

Pembahasan pertama tentang persiapan perguruan tinggi, bahwa perkuliahan daring memerlukan evaluasi mengenai persiapan perguruan tinggi, yang salah satunya adalah dari pengguna yakni mahasiswa, terutama terkait dengan peningkatan motivasi dan pemenuhan tujuan bersama untuk mengembangkan perkuliahan daring. Pada fasilitas penyelenggaraan pembelajaran daring mengenai dosen pada ragam aktivitas dan tool ASINKRON rata-rata penggunaannya untuk forum diskusi, email dan whatsapp. Hal ini perlu koreksi bagi pengampu mata kuliah untuk memanfaatkan fasilitas atau memaksimalkan dengan menerapkan penggunaan fasilitas yang lainnya. Kesiapan sistem pendukung yang tersedia di perguruan tinggi adalah 56,17\% Server dan sistem jaringan telah memadai sedangkan 41,57\% menyatakan cukup memadai (labil). Hal ini menunjukkan bahwa perguruan tinggi memfasilitasi dengan tepat sebelum memberlakukan perkuliahan daring secara menyeluruh dan berkesinambungan, Ketertarikan mahasiswa pada tampilan perkuliahan daring dalam VINESA UNESA begitu tinggi yakni 47,19\% menarik meski diikuti $39,32 \%$ biasa saja sebenarnya hal ini menjadi modal awal perguruan tinggi untuk mendukung pembelajaran daring dengan terus melakukan inovasi pada design atau tampilannya.

Pembahasan kedua adalah mengenai motivasi mahasiswa dalam pembelajaran daring. Hal ini dimulai saat mahasiswa mengetahui ada perkuliahan dengan daring 
selain dengan perkuliahan tatap muka yakni hampir 67,41\%. Hal ini kemudian ditindaklanjuti dengan persiapan mahasiswa sebelum perkuliahan daring mata kuliah dimulai yakni mahasiswa telah mengakses materi, maksudnya adalah dengan mengunduh ataupun membuka materi dalam bentuk slide PPT, kemudian hal ini diikuti dengan ketertarikan mahasiswa untuk melakukan eksplorasi pada mata kuliah lain yang masih ada dalam VINESA UNESA. Tetapi yang lebih mencengangkan, adalah mahasiswa jarang melakukan akses pada website unesa dan juga v-learn unesa (akses e learning yang lama) kemudian vinesa (akses e-learning yang baru), hal ini dibuktikan bahwa alasan mahasiswa mengikuti perkuliahan daring pada VINESA lebih pada instruksi dari dosen dan selebihnya karena pemanfaatan perkembangan ilmu pengetahuan dan teknologi (IPTEK). Hal ini menunjukkan bahwa motivasi mahasiswa saat mengikuti perkuliahan daring adalah $71 \%$ yang tergolong tinggi dengan menganggap bahwa memang e-learning adalah metode untuk perkuliahan yang cukup efektif untuk menggugah keingintahuan mahasiswa pada suatu mata kuliah, dan hal ini terbukti karena Unesa dalam beberapa tahun ini telah gencar untuk mensosialisasikan penggunaan daring untuk mata kuliah. .

Pembahasan ketiga adalah mengenai materi pada pembelajaran daring. Hal ini dmulai dengan kesesuaian materi daring dan tujuan pembelajaran mata kuliah sebesar $87,6 \%$ yang sebenarnya ini menggambarkan bahwa dosen telah melaksanakan penyusunan materi sesuai dengan RPS. Sedangkan kualitas materi berkaitan dengan kebenaran dan akurasi materi perkuliahan daring menunjukkan bahwa mahasiswa telah memiliki konsep kebenaran materi dan keakuratan materi kemudian dapat menyimpulkan bahwa kedua sifat tersebut secara tersurat ada dalam materi daring. Kemudian materi perkuliahan terutama materi daring dapat dilakukan penilaian berkaitan dengan kualitas materi berdasarkan pada keberimbangan penyajian ide materi daripada hanya deskripsi tentang materi mata kuliah. Kualitas materi berkaitan dengan ketepatan tingkat kerincian (keluasan dan kedalaman materi perkuliahan daring rata-rata menyatakan tidak tahu, hal ini disebabkan oleh ruang lingkup mata kuliah yang tidak diketahui oleh mahasiswa dan kualitas mahasiswa memahami mata kuliah dengan mendasarkan pada RPS dan bahan hukum yang tersedia sehingga mahasiswa tidak dapat memberikan penilaian sampai sejauh mana keluasan dan kedalaman materi.

Ragam objek ajar yang digunakan dosen dalam pembelajaran daring adalah teks, audio, visual, audio visual, dan pada pendapat mahasiswa bahwa ragam obyek ajar tertinggi adalah menggunakan audio visual. Hal ini menunjukkan bahwa kebutuhan akan mengkolaborasi untuk menyusun materi daring yang menarik misalnya dengan animasi games dan simulasi, sehingga diperlukan waktu dan tenaga yang memadai untuk menyempurnakan materi daring mata kuliah PHI ini. Strategi dalam mengembangkan objek pembelajaran daring PHI ini ada beberapa cara yakni membeli, membuat sendiri, memodifikasi, mengambil objek ajar, dan menurut mahasiswa bahwa pilihan PHI yaitu dengan cara membuat sendiri materi daring dan memang Dosen PHI telah menyusun sendiri obyek pembelajaran, sehingga tidak ada plagiasi atau orisinil. Hal paling penting ada pada pembahasan terakhir yakni mengenai efektifitas pencapaian tujuan pembelajaran dengan perkuliahan daring dibanding perkuliahan tatap muka dan $76,4 \%$ mahasiswa menyatakan efektif, kemudian perkuliahan daring dengan perkuliahan tatap muka dengan komposisi yang seimbang yakni masing-masing 50\%. Jadi interaksi mahasiswa dengan dosen melalui pembelajaran daring ternyata telah memberikan variasi tersendiri yang berbeda dengan perkuliahan tatap muka, dan mahasiswa lebih menyukai pembelajaran daring sebagai variasi cara 
mengembangkan dan penyampaian materi dan ada kesepakatan bahwa ada keefektifan saat pencapaian tujuan pembelajaran daring tersebut.

\section{Simpulan}

Pemahaman mahasiswa pada mata kuliah PHI dengan mengalami peningkatan setelah ada interaksi mahasiswa dengan dosen melalui pembelajaran daring PHI. Instrument penelitian menunjukkan bahwa pembelajaran daring telah mendapatkan dukungan dari perguruan tinggi dan dosen, yakni dalam menyediakan sarana dan prasarana dan dosen menyiapkan materi ajar yang sesuai dengan tujuan pembelajaran daring tersebut. Mahasiswa telah menunjukkan motivasi yang cenderung meningkat sebab mahasiswa memerlukan variasi tersendiri yang berbeda dengan perkuliahan tatap muka, dan mereka lebih menyukai pembelajaran daring sebagai variasi cara mengembangkan dan penyampaian materi.

\section{Daftar Pustaka}

Afriani. 2018. Pemanfaatan Open Educational Resources (OER) Dalam Tutorial Online. Jurnal Pendidikan Terbuka dan Jarak Jauh, Volume 19, Nomor 2, September 2018, 65-72. Universitas Terbuka

Degeng, I. N. S. 1991. Ilmu Pengajaran Taksonomi Variabel. Jakarta: Depdiknas, Dirjen Dikti. P2LPTK.

Harmanto. 2001. Pengembangan Pembelajaran Mata Kuliah Metodologi Penelitian dengan Menggunakan World Wide Web. Malang: Tesis, Tidak diterbitkan.

Kanwar \& Uvalic-Trumbic, dikutip dalam Dina Mustafa. Tutisiana, 2014. Model Pengembangan Kemampuan Dosen dan Guru dalam Merancang Sumberdaya Pembelajaran Terbuka Daring (Online Open Educational Resources/Program/Courseware).
Laporan Penelitian Hibah Bersaing Universitas Terbuka.

Moeljatno. Undang-undang Nomor 1 Tahun 1946 tentang Peraturan Hukum Pidan di Indonesia (Kitab Undang-Undang Hukum Pidana). Bandung. Sinar Grafika.

Nurdin, Encep Syarief. 2016. Analisis Materi Dimensi Implementasi Kebijakan Publik Pada Materi Kurikulum Pendidikan Kewarganegaraan Di Perguruan Tinggi. Sosiohumanika: Jurnal Pendidikan Sains Sosial Dan Kemanusiaan, Vol.9 (1). Bandung, Indonesia: Minda Masagi Press and UPI Bandung, ISSN 1979-0112.

Republik Indonesia. Undang-undang Dasar Republik Indonesia 1945. Jakarta. Sinar Grafika.

Republik Indonesia. Undang-undang No. 8 Tahun 1981 tentang Kitab UndangUndang Hukum acara pidana. Sinar Grafika. jakarta.

Republik Indonesia. Undnag-undang Nomor 5 Tahun 1960 tentang Undang-undang Pokok Agraria. Jakarta. Pradnya Paramita.

Republik Indonesia. Kitab undang-undang Hukum Dagang. Jakarta. Pradnya Paramita.

Sandra Sukmaning Adji, Tangerang Selatan. 2014. Pemanfaatan Open Educational Resources (Oer) Pada Pembelajaran Online Tentang Pemanasan Global Dan Perubahan Iklim. Universitas Terbuka. Seminar Nasional Riset Inovatif II, ISSN : 2339-1553.

Susilo. Jumlah Penduduk Indonesia 259 Juta

Https:/Nasional.Kompas.Com/Re ad/2011/09/19/10594911/Jumlah diakses Tanggal 19 April 2019.. 
The World Bank Indonesia, 2012. Perkembangan Ekonomi Global. Perkembangan Ekonomi Keuangan dan Kerja Sama Internasional Triwulan II - 2012. Grup Kerjasama dan Studi Asean Departemen Internasional Bank Indonesia, Jakarta.
Utrecht. 1989. Pengantar dalam Hukum Indonesia. cetakan ke-XI Jakarta, Ichiar Baru, 